\title{
HISTOLOGICAL STRUCTURE OF THE THYROID GLAND IN APOLIPOPROTEIN E DEFICIENT FEMALE MICE AFTER LEVOTHYROXINE APPLICATION
}

\author{
Irena Petrova, Elida Mitevska, Zorica Gerasimovska, Liljana Milenkova, Nevena Kostovska
}

Department of Histology and Embryology, Medical Faculty, Skopje, R. Macedonia

Corresponding Author: Irena Petrova, Department of Histology and Embryology, Skopje, R. Macedonia, Tel: +389 (0)2 725492 72, E-mail: irena.petrova11@yahoo.com

\begin{abstract}
The aim of this study was to determine the histological characteristics of the thyroid gland in ApoE $\mathrm{KO}^{-/}$mice following the application of levothyroxine (l-thyroxine).

A total of 12 female ApoE $\mathrm{KO}^{-/}$mice were divided into two groups. A control group of mice received distilled water and the experimental group received l-thyroxine dissolved in drinking water at a daily dose of $2 \mu \mathrm{g} / \mathrm{ml}$, over 12 weeks. The paraffin sections were processed with the usual haematoxilin-eosin technique of staining.

Qualitative histological analysis demonstrated: the presence of large distended follicles in the peripheral areas of the gland; fulfillment of the lumen of follicles with an ample amount of colloid; complete absence of resorptive vacuoles in the colloid; a flattened follicullar epithelium. Morphometric assessment showed a significant increase in the diameters of follicles in the peripheral areas of the gland and a significant decrease in the height of the follicullar epithelium ( $p<0,001)$.

Our results demonstrated that l-thyroxine causes characteristic morphological changes in the structure of the thyroid gland in the direction of the occurrence of hyperthyroidism.
\end{abstract}

Key words: thyroid gland, $\mathrm{ApoE} \mathrm{KO}^{-/}$female mice, morphometric analysis, 1-thyroxine.

\section{Introduction}

The thhyroid gland is an endocrine gland, producing hormones which play a role in the basal metabolism of the body. Thyroid hormone increases the metabolic rate of cells of all tissues in the body [1]. This means that the thyroid gland has a leading role in the metabolism of the lipoproteins in the body.

When the gland is in a normal physiological status histo-morphologically it is presented with round or oval follicles. The largest follicles are located in the peripheral zone and the follicles of smaller sizes are in the central zone of the gland. The walls of the follicles are lined with cuboidal thyroid epithelium in one layer, which has fluctuations in height depending on the functional status of the gland [8]. The lumen of the follicles is filled with an eosi- nophilic, homogenous colloid, containing resorptive vacuolles [9, 13]. When the thyroid gland is in a hyperthyroid status, there are morphological changes in its structure: changes in order to resize follicles, the occurrence of follicles with an irregular shape, a changes in the height and shape of the thyroid epithelium and the amount of colloid filling the follicles [5].

Thyrocytes secrete hormones into the lumen of the folliclles, stored as colloid and this presents a depot for these hormones. Thyroxine is released from thyroglobulin by proteolysis and secreted into the blood. Thyroxine is peripherally deiodinated to form triiodothyronine $\left(\mathrm{T}_{3}\right)$ which exerts a broad spectrum of stimulatory effects on cell metabolism. Levothyroxine (l-thyroxine) is a synthetically prepared levoisomer of thyroxine, typically used to treat hypothyroidism [4]. 
L-thyroxine is a synthetic form of the thyroid hormone thyroxine and is often used for the treatment of hypothyroidism and thyroid hormone deficiency. It has the ability to lower the thyroid-stimulating hormone (TSH), a hormone that is considered goitre-inducing $[10,11]$.

Morphological examination of the thyroid gland is extremely important because changes in the structure of the gland indicate its functional status, or they may indicate a medically induced state of hypothyroidism or hyperthyroidism (Serakides et al.) [3].

The aim of this study was to determine histo-morphological changes in the structure of the thyroid gland after 1-thyroxin treatment in dislipidemic apolipoprotein $\mathrm{E}$ deficient female mice $\left(\mathrm{ApoE} \mathrm{KO}^{-/}\right)$.

In order to investigate the influence of thyroid status on the metabolism of lipo $\neg$ proteins, we used exactly these mice because they have a specific genetic base, C57BL/6, which gives spontaneously developed atherosclerosis. The establishment of this animal model allows testing requirements of the occurrence of atheros $\neg$ clerosis and its relation to thyroid function.

This paper is part of a larger study de $\neg$ dicated to the emergence and development of atherosclerosis associated with impaired function of the thyroid gland.

Therefore, the aim of the study was to determine the effect of 1-thyroxine on the histological structure of the thyroid gland in female $\mathrm{ApoE} \mathrm{KO}^{-/}$mice.

\section{Material and methods}

The experiment included 12 dislipidemic apolipoprotein $\mathrm{E}$ deficient female mice (ApoE $\left.\mathrm{KO}^{--}\right) .5$ week old animals were divided into two groups. Each group was represented with 6 animals: the first one, the control group, received distilled water, the second one, the experimental group, received L-thyroxine diluted in the drinking water at a daily dose of $2 \mu \mathrm{g} / \mathrm{ml}$. The drug was administered for 12 weeks in an attempt to obtain an iatrogenic status of thyroid dysfunction in the animals (hyperthyroidism).

The animals were acclimatised to a room temperature of $18-22^{\circ} \mathrm{C}$, submitted to a regimen of 12 hours of light and 12 hours of darkness, supplied with water and food ad libitum.
All the procedures concerning manipulation with the animals were in accordance with the legal legislatives for experimental work with laboratory animals.

After the treatment period of 12 weeks, the animals were sacrificed using ketamine ( 90 $\mathrm{mg} / \mathrm{kg}$ i.p.) and xylazine (10 $\mathrm{mg} / \mathrm{kg}$ i.p.), as is described in the literature $[16,18]$. One type of anaesthetic is ketamine, used mainly in animal research. Ketamine acts as a non-competitive antagonist of N-methyl-D-aspartate (NMDA), one of the glutamate receptors. A consequence is a reduction of the action of glutamate, which is essential for neuronal survival. Ketamine can also be combined with xylazine, a painkiller and muscle relaxant. Xylazine is an agonist of alpha 2 adrenergic receptors located presynaptically. These receptors reduce noradrenaline release by inhibiting the influx of calcium in the neuron, with a consequent hypotensive and tranquilizing effect [17]. In one study it has been observed that the ketamine/xylazine combination markedly suppresses cardiac function, characterized by reductions in heart rate [18]. The animals were not sacrificed with ether because of its hepatotoxic effect and disturbance of the biochemical prcesses in the blood [19]. Also, animals were not sacrificed by bleeding, because we need the blood for use in additional analyses for further investigations.

Thyroid glands were extirpated and fixed in buffered formalin, processed to the routine technique of paraffin inclusion [6] and stained according to the haematoxylin-eosin method [7]. Both histological (qualitative) and morphometric (quantitative) analyses were done. In order to measure the diameters of the follicles and the height of the thyroid epithelium in the peripheral and the central zone of the thyroid gland, we assessed the sections of the middle part of the gland. For the morphometric analysis we used an eyepiece (enlargement 40 and $100 \times$ ), with a buil-in micrometer ruler with 100 length divisions, using light microscope, model Olympus CX21FS1. Diameters of the follicles were measured on 10 randomly selected follicles in the peripheral and 10 follicles in the central zone of the gland. The height of thyroid epithelium was determined in the same follicles.

Statistical elaboration of the morphometric results was performed using the Statistica software program, version 7.0, defining the 
means and standard deviation of each morphometric parameter. The differences between the groups were tested using the Student-Newman-Kewls test (t-test) and the correlation was set using Pearson`s coefficient ( $\mathrm{p}$ ) with a level of significance $\mathrm{p}<0.05$.

\section{Results}

\section{Qualitative assessment}

In the control group of animals, thyroid glands presented with round shaped or oval follicles of different size. Larger follicles were located in the peripheral zone and those with a smaller dimension were noted at the central part of the gland. Their wall presented with a low cuboidal thyroid epithelium in one layer. The cells had a smooth apical surface which was in direct contact with the colloid. The lumen of the follicles was filled with homogenic, eosinophillic colloid. In the peripheral parts of the colloid rare and small resorptive vacuoles were noticed. The interstitial connective tissue of the gland presented with thin fibrous septa between the follicles (see Fig. 1).

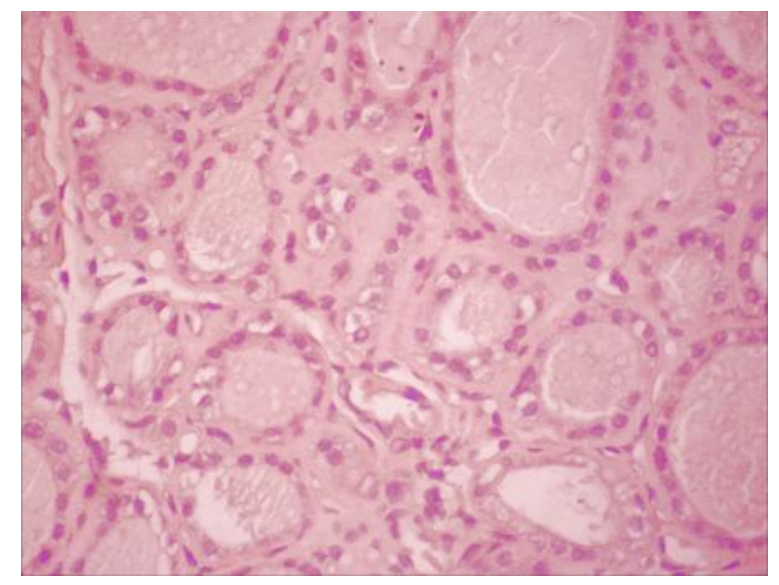

Figure 1 - Thyroid gland in ApoE $\mathrm{KO}^{-/}$female mice control group. Round and oval follicles, lined with cuboidal thyroid epithelium and filled with vacuolized colloid. $H \& E(10 \times 40)$

In the experimental group of animals, thyroid glands presented with follicles of various sizes with a dominance of large and distended follicles in the peripheral zone of the gland. Contrary to that, the dimensions of the follicles were lowered in the central zone of the gland. The thyroid epithelium was flattened and squamous in the follicles of the two zones of the gland. Cell nuclei were also flattened and hyperchromatic. Follicles contained a large qu- antity of homogenous, eosinophilic colloid. There were no resorptive vacuoles inside the colloid. The interstitium of the gland presented with scanty connective tissue between the follicles, when compared with the control group (see Fig. 2, 3).

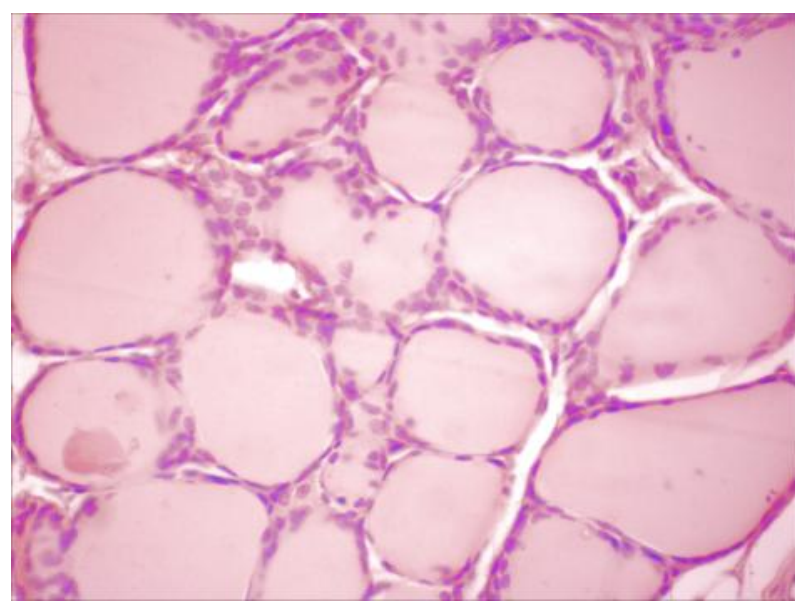

Figure 2 - Thyroid gland in ApoE $\mathrm{KO}^{-/}$female mice experimental group. Distended follicles with flattened epithelium, filled with colloid. $H \& E(10 \times 40)$

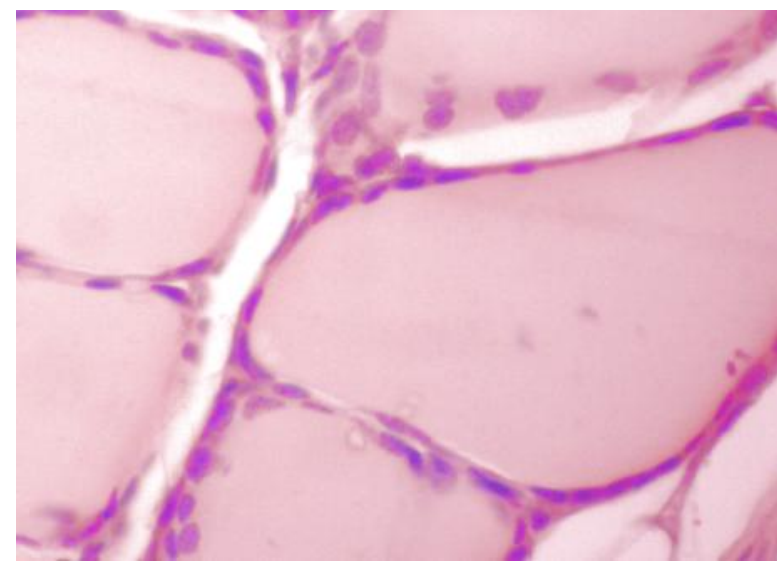

Figure 3 - Thyroid gland in ApoE $\mathrm{KO}^{-/}$female mice experimental group. Flattened thyroid epithelium in distended follicles filled with colloid, $H \& E(10 \times 100)$

\section{Quantitative assessment}

Size of the follicles in the thyroid gland

In the control group of animals the diameter of the follicles depends on their localization in the gland. Peripheral follicles have a greater diameter when compared with central follicles in the gland. The comparison of the mean values of follicular diameter in the peripheral zone of the gland between the control and treated group of mice has shown an insignificant increasing of this parameter: from 108.95 $\pm 20.47 \mu \mathrm{m}$ as was found in the control group 
to $125.05 \pm 43.73 \mu \mathrm{m}$ after 1-thyroxine administration $(\mathrm{p}=0.102)$. Contrary to that, the diameter of the central follicles was significantly decreased from $68.45 \pm 17.57 \mu \mathrm{m}$ (control group) to $52.20 \pm 8.80 \mu \mathrm{m}$ (group treated with 1-thyroxine), $\mathrm{p}<0.001$ (see Table 1).

Table 1

Size of follicles in thyroid gland in female ApoE $\mathrm{KO}^{-/-}$mice

\begin{tabular}{lcccc}
\hline \multicolumn{1}{c}{ Diameter $(\mu \mathrm{m})$} & Control group $(\bar{x} ; \underline{\sigma})$ & Experimental group $(\bar{x} ; \underline{\sigma})$ & t-test & $\mathrm{p}$ \\
\hline Peripheral follicles & $108.95 \pm 20.47$ & $125.05 \pm 43.73$ & -1.66 & 0.102 \\
Central follicles & $68.45 \pm 17.57$ & $52.20 \pm 8.80$ & 4.13 & 0.001 \\
\hline $\mathrm{p}<0.05$ (significant level) & & & &
\end{tabular}

Height of the epithelium in the follicles

Morphometric assessment showed statistical significance in the decreasedheight of the follicular epithelium, in both peripheral and central follicles. The height of the thyroid epithelium in the peripheral follicles was $9.9 \pm$ $2.10 \mu \mathrm{m}$ in the control group of mice and was significantly decreased to $4.95 \pm 1.16 \mu \mathrm{m}$ after 1-thyroxine treatment. The height of the thyroid epithelium of the central follicles significantly decreased from $10.3 \pm 1.95 \mu \mathrm{m}$ in the control group to $4.10 \pm 1.22 \mu \mathrm{m}$ after l-thyroxine application ( $<<0,001)$; see Table 2.

Table 2

Height of follicular epithelium in female ApoE $\mathrm{KO}^{--}$mice

\begin{tabular}{lcccc}
\hline Height of epithelium $(\mu \mathrm{m})$ & Control group $(\bar{x} ; \underline{\sigma})$ & Experimental group $(\bar{x} ; \underline{\sigma})$ & t-test & $\mathrm{p}$ \\
\hline Peripheral follicles & $9,9 \pm 2.10$ & $4.95 \pm 1.16$ & 10.29 & 0.0000 \\
Central follicles & $10,3 \pm 1,95$ & $4.10 \pm 1.22$ & 13.44 & 0.0000 \\
\hline $\mathrm{p}<0.05$ (significant level) & & & &
\end{tabular}

\section{Discussion}

The normal histological structure of the thyroid gland in the athyreotic condition is presented with round shaped or oval follicles of different size. Larger follicles are located in the peripheral zone and those of smaller dimension are noted at the central part of the gland. Their wall is lined by one layer of cubical or low columnar epithelium. Cell nuclei are round and euchromatic. Cell cytoplasm is filled with colloid resorptive droplets in the apical part of the cell. These cells produce thyroxine and triiodthyronine. Follicles are filled with colloid, a depot for these hormones, which contains small resorptive vacuoles. There is another type of cell on the basal lamina of the follicles, parafollicular cells, and these produce the hormone calcitonine [9].

Among the population of Macedonia the presence of dysfunction of the thyroid gland is often observed $[14,15]$. The occurrence of hy- pothyroidism (a state in which the thyroid gland does not produce a sufficient amount of the thyroid hormones thyoxine and triiodothyronine) is especially common. This condition of the body must be treated by drug (hormone) therapy. On the other hand, drug therapy may lead to structural changes in the tissues of the thyroid gland.

In our study we analysed the histological structure of the thyroid gland according to certain qualitative and quantitative parameters. Qualitative assessment of the gland in the experimental group of animals showed changes in the histological structure of the thyroid gland. Changes were noticed in the size and the shape of the follicles. They were large and distended in both peripheral and central parts of the gland. The epithelium lining the follicles was flattened. Cell nuclei were hyperchromatic. The lumen of follicles was filled with a lot of colloid and there were no resorptive vacuoles in 
the colloid. Similar findings have been presented by other authors, Ferreira et al. [5]. Qualitative analysis of the morphological changes of the thyroid gland in our study indicated a medically induced state of hyperthyroidism. Quantitative assessment of the gland was based on quantitative measurment of the size of the follicles in the peripheral and central parts of the gland and height of the follicular epithelium. Morphometric analysis of the height of the follicular epithelium showed statistically significant differences when compared with the control group. In the control group of female ApoE $\mathrm{KO}^{-/}$mice the height of the epithelium in the peripheral follicles was $9.9 \pm 2.10 \mu \mathrm{m}$ and in the group of animals treated with 1-thyroxine this value was $4.95 \pm 1.16 \mu \mathrm{m}$. Quantitative morphometric analysis confirmed the qualitative analysis. In the study made on female mice by Ferreira et al., the values for the height of the follicular epithelium was $3.7 \pm 0.28 \mu \mathrm{m}$ in the euthyroid group and $2.31 \pm 0.22 \mu \mathrm{m}$ in the hyperthyroid group [5]. The results of the histological analysis of our study were very similar to the results obtained by Ferreira et al. Shalaby NM. demonstrated thyroid glands with variable changes in albino rats injected with amiodarone for 3 months: a few samples were more or less similar to the control ones, while others showed a dilated lumen engorged with colloid and lined with flat squamous cells [12).

The results of this study are similar to the results found in the literature concerning the morphological changes seen in the thyroid gland, in terms of matching hyperthyroidism. This paper makes a contribution to the research because it is set with dislipidemic apolipoprotein $\mathrm{E}$ deficient female mice (ApoE KO-/-), a new animal model that allows examination of the relationship of atherosclerosis with the state of hyperthyroidism.

Morphological assessment of the thyroid gland in female ApoE $\mathrm{KO}^{--}$mice treated with 1thyroxine confirmed histological changes in the parenchima of the gland in addition to hyperthyroidism.

\section{Conclusion}

The results obtained in this investigation have shown that 12 weeks application of 1-thyroxine at a daily dose of $2 \mu \mathrm{g} / \mathrm{ml}$ provoked distended and enhanced follicles in the peripheral parts of the gland, filled with lots of colloid without resorptive vacuoles and flattened epithelium in the follicles of both parts of the gland, its peripheral and central zone.

\section{REFERENCES}

1. Serafimoski V. Interna medicina, 1-st ed. Kumanovo: Makedonska riznica; 2003.

2. Kobayashi et al., 2000.

3. Serakides et al., 2002; 2005.

4. Vaidya B, Pearce SH. Management of hypothyroidism in adults. BMJ (Clinical research ed.). 2008; 337:a801. doi:10.1136/bmj.a801. PMID 18662921.

5. Ferreira E, Silva A.E, Serakides R, Gomes A.E.S, Cassali G.D. Model of induction of thyroid dysfunctions in adult female mice, Arq. Bras. Med. Vet. Zootec. 2007; v. 59, n. 5, p. 1245-1249.

6. Prophet EB, Mills B, Arrington JB. et al. AFIP laboratory methods in histotechnology. Washington: American Registry of Pathology, 1992.

7. Luna LG. (Ed). Manual of histologic staining methodsof the Armed Forces Institute of Pathology. 3 ed. NewYork: Mac Graw Hill, 1968.

8. Fisman MC, Hofman ER, Klausner RD, Taler MS, eds. Medicina, 1 st ed. Skopje: Ars Lamina DOO, 2011.

9. Ros MH, Vojcic P. Histologija tekst i atlas, 5th ed. Skopje: Tabernakul; 2010.

10. Svensson J, Ericsson UB, Nilsson P, et al. Levothyroxine treatment reduces thyroid size in children and adolescents with chronic autoimmune thyroiditis. The Journal of Clinical Endocrinology and Metabolism. 2006; 91(5): 1729-34. doi:10.1210/jc.20052400. PMID 16507633

11. Dietlein M, Wegscheider K, Vaupel R, Schmidt M, Schicha H. "Management of multinodular goiter in Germany (Papillon 2005): do the approaches of thyroid specialists and primary care practitioners differ?". Nuklearmedizin. Nuclear Medicine. 2007. 46 (3): 65-75.

12. Nawar M. Shalaby. Histological Study of the Effect of Amiodarone on Thyroid Follicular Cells in Albino Rat and its Management Using Carbimazole with and without. Prednisolone, Egypt. J. Histol. Vol. 32, No. 2, Dec. 2009: 306-314.

13. Stivens A, Lowe J. Human histology, 2-nd ed. London: Mosby; 1997.

14. Kocova M. Avtoimun tiroidit vo detstvoto, Novini vo pedijatrijata/Godisna revija. 2009; 45-54.

15. Kocova M, Anastasovska V, Sukarova-Angelovska E, Gjurkova B. Neonatal Thyroid Screening in the Republic of Macedonia. Balkan Journal of Medical Genetics. 2006; 9: 124.

16. Laboratory Animal Anesthesia. 1996. Flecknell P. Academic Press, London. 274 pp.

17. Lima J.P, Ariga S, Velasco I and Schochat E. Effect of the ketamine/xylazine anesthetic on the auditory 
brainstem respons of adult gerbils. Braz $\mathbf{J}$ Med Biol Res. 2012; 45(12): 1244-47.

18. Feng Y, Chai J, Chu W, Ma L, Zhang P, Duan H. Combination of ketamine and xylazine exacerbates cardiac dysfunction in severely scalded rats during the shock stage. Experimental and Therapeutic Medicine. 2013; 6(3): 641-648.

19. Animal Care and Use Policies and Guidelines. Use of Ether for Animal Anesthesia at Johns Hopkins University (Revised by the JHU Joint Heath Safety and Environment/Animal Care and Use Committee 02/22/06)

Р ези и е

\section{етров , лид}

Институт за хистологија и ембриологија, Медицински факултет, Универзитет „Св. Кирил и Методиј“, Скопје, Р. Македонија

Целта на оваа студија беше да се одредат хистолошките карактеристики на тироидната жлезда кај ApoE $\mathrm{KO}^{-/-}$глувци по апликација на левотироксин.

Вкупно 12 женски АроE $\mathrm{KO}^{-/}$глувци беа поделени во две групи. Контролната група животни примаше дестилирана вода, додека експерименталната група животни примаше левотироксин растворен во водата за пиење во дневна доза од $2 \mu \mathrm{g} / \mathrm{ml}$, во период од 12 недели. Парафинските пресеци беа обработени со вообичаениот хематоксилин-еозин метод на боење.

Квалитативната хистолошка анализа покажа: присуство на големи дистендирани фоликули во периферните делови на жлездата, исполнетост на луменот на фоликулите со голема количина колоид, целосно отсуство на ресорптивни вакуоли во колоидот, плочест фоликуларен епител. Морфометриската анализа покажа сигнификантно зголемување на дијаметарот на фоликулите во периферните делови на жлездата и сигнификантно намалување на висината на фоликуларниот епител (р < 0,001).

Нашите резултати покажаа дека левотироксинот предизвикува карактеристични морфолошки промени во структурата на тироидната жлезда во правец на појава на хипертироидизам.

лучни зборови: тироидна жлезда, АроЕ $\mathrm{KO}^{-/}$ женски глувци, морфометриска анализа, левотироксин. 